\title{
OCCURRENCE OF ATTINI (FORMICIDAE) IN TWO GEOMORPHOLOGICAL PROVINCES OF RIO GRANDE DO SUL, BRAZIL
}

\author{
Elena Diehl $^{1}$, Eduardo Diehl-Fleig ${ }^{2} \&$ Emília Zoppas Albuquerque ${ }^{3}$ \\ ${ }^{1}$ Laboratório de Insetos Sociais. São Leopoldo, RS, Brasil. Pesquisadora CNPq aposentada. ediehl@pq.cnpq.br. \\ ${ }^{2}$ Bolsista de Mestrado CNPQ.Mestrado em Entomologia - ESALQ (Piracicaba), USP - SP, Brasil. \\ ${ }^{3}$ Museu Emílio Göeldi, Belém, PA. Brasil. Bolsista de Doutorado CNPQ. emilia_albuq@ @otmail.com
}

\begin{abstract}
This paper deals with the occurrence of Attini (Hymenoptera, Formicidae) in two geomorphological regions of the Rio Grande do Sul State, Brazil The ant collections were made in 65counties of the Taquari Valley (Central Depression) and in 75 counties of the North Littoral (Coastal Plain), from1994 to 1997. Of the Myrmicinae we collected only the upper Attini. Seventeen (17) species of the Attinisubtribewere found, being one of the genus Atta and 16 of Acromyrmex. This number represents $70.83 \%$ of the leaf-cutting ants in the state, and $21.52 \%$ of the known species. The more frequent leaf-cutting ant was Atta sexdens, but it was not found in the Coastal Plain. Of the Acromyrmex genus 16 species were collected in the two biogeographic regions but not all species were found in the same region, as well as frequencies differed from county to county. Not either one of the recorded species is endemic to one state region, but the recordings provided increased knowledge on the species geographical distribution.
\end{abstract}

Keywords: Leaf-cutting ants, occurrence, North littoral, Taquari Valley, Rio Grande do Sul

\section{OCORRÊNCIA DE ATTINI (FORMICIDAE) EM DUAS REGIÕES GEOMORFOLÓGICAS DO ESTADO DO RIO GRANDE DO SUL, BRASIL}

\section{RESUMO}

Este artigo trata da ocorrência de Attini (Hymenoptera, Formicidae) em duas regiões geomorfológicas do estado do Rio Grande do Sul. As coletas foram feitas em 65 municípios do Vale do Taquari (Depressão Central) e 75 do Litoral Norte (Planície Costeira). Dentre os formicídeos, apenas as Attini superiores (Myrmicinae) foram selecionadas. A formiga cortadeira mais frequentemente encontrada na Depressão Central foi Atta sexdens, mas não encontrada na 
Planície Costeira. Do gênero Acromyrmex foram coletadas 16 espécies nas duas províncias, porém nem todas as espécies foram encontradas na mesma região, assim como também diferiram em frequência nos distintos municípios.

Palavras-chave: Formigas cortadeiras, ocorrência, Litoral norte, Vale do Taquari, Rio Grande do Sul

\section{INTRODUCTION}

The fungus-eating ants (Formicidae, Myrmicinae, Attini,Attina) distinguish themselves from the other Formicidae by their behavior of growing a symbiotic fungus (MEHDIABADY \& SCHULTZ, 2010). The Attina subtribe ants are exclusive to the Americas (WEBER, 1982), and they presently comprise 16 alive genera and a fossil genus (BOLTON, 2017). Many species show a wide geographical distribution from the Chubut province, in Argentina, to the northeast region of the United States (WEBER, 1982; RABELING et al., 2007 DELABIE et al., 2011). The mostly derived ones belong to the Atta and Acromyrmex genera (BRANSTETTER et al., 2017). They are characterized by cutting different plant species, mainly the introduced plants. They occur in different environments, such as humid or dry forests, the Cerrado, the Pampa, deserts, sandbanks and caatingas (MEDIAHBADI \& SCHULTZ, 2010, DELABIE et al. 2011; BRANSTETTER et al., 2017).

In Rio Grande do Sul, to the north, there is a volcanic plateau of up to 1,000 $\mathrm{m}$ high where araucaria forests can be seen. In the central region, at the South-river shield, the Paleozoic plateaux shows low forests. Limited by these two regions for one side and by the Atlantic Ocean for another side the Coastal Plain covers more than $600 \mathrm{~km}$ long and more than $80 \mathrm{~km}$ wide, between the larger and medium portions of the Jacui river and its tributaries (RAMBO, 1994; CORDAZZO \& SEELIGER, 1995).

That is why they have been highlighted and have been the topic of many studies, specially the studies related to the biological aspects and the geographical distribution. Despite studies on the species distribution, these studies have been dispersed, lacking on updating or showing major gaps (DELABIE et al., 2011). In such context, and aiming at a better geographical distribution of 
the leaf-cutting ants in the state, a survey of the leaf-cutting ants was carried out at the Taquari Valley (Central Depression), together with EMATER-RS technicians, besides other studies conducted in the state North Littoral (Coastal Plain).

Originally, two main plant formations occur in the state, forests and fields, occupying around $34 \%$ and $46 \%$ of the total area, respectively. The remaining portion is occupied by littoral vegetation, flooding wetlands and other plant formations (CORDAZZO \& SEELIGER, 1995).

\section{MATERIAL AND METHODS}

With the aim of a better knowledge of the geographical distribution of the leaf-cutting ants of Rio Grande do Sulstate and to add to the already existing data, a survey was conducted in 38 municipalities of the Taquari Valley and in other 48 municipalities at the North Littoral of the state, with the help of EMATER-RS technical staff. Thus, in each municipality ant collections were carried out in trails and/or inside the nests $\left(\mathrm{N}^{\circ}\right.$ of ants $=20 /$ nest or trail). The finding of at least one nest of the referred species was regarded as occurrence rate within the municipality limits. In the collected material in these counties there was the addition of collections conducted in different periods without EMATER-RS participation, leading to a total of 65 municipalities of the Taquari Valley, and 75 municipalities of the North Littoral of the state. The identification key of Mahyé-Nunes (1993) was used based on the worker ants' morphological characteristics.

\section{RESULTS AND DISCUSSION}

The collected samples in a standardized way were preserved in a humid and/or dry way, and they represent the main ecosystems of the geomorphological provinces in Rio Grande do Sul, precisely the Taquari Valley in the Central Depression, and the North Littoral in the Coastal Plain. In a humid way there are 639 lots of leaf-cutting ants collected in 38 counties of the Taquari Valley. In these lots, besides Atta sexdens there are samples of Acromyrmex crassispinus, Ac. heyeri, Ac. hispidusfallax, Ac. laticeps, Ac. lobicornis, Ac. lundi, Ac. niger, Ac. rugosus, Ac. striatus, Ac. subterraneus, and also a not yet identified species, possibly a new one for the state (Acromyrmex sp.1). Besides this species, there is a second new Acromyrmex species (Ac. sp.n.2) collected in the region Canela (DIEHL \& DIEHL-FLEIG, 2003, not published)

From the North Littoral, the humid collection still comprises 1,020 lots collected in 48 municipalities. In these lots, besides the 11 previously mentioned species, there are samples of 
Ac. ambiguus, Ac. aspersus, and Ac. disciger. It still encompasses 536 lots of represent ants of 37 genera of seven subfamilies (Dolichoderinae, Ecitoninae, Ectatomminae, Formicinae, Heteroponerinae, Myrmicinae, and Ponerinae), whereas in the dry way there are represent ants of 56 genera of nine subfamilies (Amblyoponinae and Pseudomyrmecinae, besides the seven previously mentioned subfamilies).

In the Catalogue of Neotropical Ants Kempf (1972) refers to 208 species for Rio Grande do Sul, and in the Catalogue Addendum, Brandão (1991) adds other 13 species. In the Formicidae Collection of the Social Insects Laboratory, 24 species correspond to new recordings for the state (Acromyrmex aspersus, Acromyrmex disciger, Acromyrmex landolti, Acromyrmex niger, Acromyrmex subterraneus bruneus, Acropyga goeldii, Brachymyrmex heeri, Camponotus renggeri, Cardiocondyla emeryi, Cephalotes depressus, Cephalotes incertus, Eciton burchelli, Hypoponera foreli, Monomorium floricola, Oxyepoecus crassinodus, Pachycondyla laevigata, Pheidole diligens, Pheidole triconstricta, Pogonomyrmex lobatus, Pseudomyrmex acanthobius, Solenopsis invicta, Tetramorium bicarinatum, Trachymyrmex holmgreni, and Trachymyrmex tucumanus).Acromyrmex rugosus rugosus, referred only by Gonçalves (1961) for Rio Grande do Sul, was also collected.

It is worth highlighting that A. heyeri and A. striatus are particularly frequent in many environments of the Central Depression and the Coastal Plain, although they also occur in the state of Santa Catarina, Uruguay and Argentina. Therefore, these two species live both in temperate and subtropical regions. Not any of the species now recorded are endemic, although these recordings play a part to increase the knowledge base of the species' geographic distribution (MAHYÉ-NUNES \& DIEHL, 1994; DIEHL \& DIEHL-FLEIG, 1997). According to Kuznezov (1949), flora and fauna diversity decreases as the distance in relation to the Equator increases. Thus, it was expected a smaller richness of species in this state when compared to the tropical zones' richness.

As reported by Della Lucia (1993) and Diehl (1995) the higher frequencies of the occurrence of the Acromyrmex and also the Atta species are found in places with larger anthropic actions resulting from monocultures, agrochemicals usage, mining areas, growing urbanization, among other things. The success of the colonies foundation process has to do with a series of environmental factors (WEBER, 1982; HÖLLDOBLER \& WILSON, 1990; DIEHL \& ROCHA, 1998). So, the great loss of early colonies of Atta. and Acromyrmex besides resulting from 
unfavorable abiotic conditions (rainfall, drought) is due to the presence of higher-order groups of predators, such as some mammals (armadillo, anteater) and some birds (great kiskadee, redbelled thrush). As regards the arthropods, mainly spiders and insects, there occur attacks by other ants; pathogens, such as some nematodes, fungi and viruses (MACHADO et al., 1988; HÖLLDOBLER \& WILSON, 1990; SPECHT et al., 1994; BRANDÃO \& MAHYÉ-NUNES, 2001). As these are the more often detected factors in less disturbed environments, the natural control of the population density is also more severe in these areas (BRIAN, 1983). Also, the lack of hyphae of symbiotic fungus or the fact that females are not fertilized, there is a decrease of the success of colony foundation process (DELLA LUCIA, 1993). After the critical phase, when the first worker ants are foraging and carrying out the other activities, colony survival tends to increase (BRIAN, 1983). Even in such condition, according to Diehl (1995), the young colonies may be attacked by adult non-specified colonies.

In the Taquari Valley (Table 1) A.sexdens was the species occurring in most of the municipalities(about 90\%), except for the North Littoral. There (Table 2) the species was found in four counties only (6.15\%). The Acromyrmex species was present in practically all places in the Taquari Valley, although with distinctive rates in each locality. Ac. crassispinus, as well as Ac.striatus, occurred in 11 municipalities search (14.67\%), whereas Ac. laticeps was found in 13 (17.33\%) places pointing to that three species are very common in the state. Species with less frequencies were Ac.niger and Ac.lundi, each one found in 5.33\% of the municipalities, and Ac. subterraneus $(4.00 \%)$ as well.

In the North Littoral, the Acromyrmex species was collected in 65 municipalities amounting to an occurrence rate of $93.85 \%$ (Table 2). Species with lower frequencies were $A c$. lobicornis, Ac. niger, and Ac.subterraneus, each one with an occurrence rate of 3.08\%. The species with the highest frequencies were, respectively, Ac.heyeri (16.92\%) and Ac. striatus that occurred in $13.85 \%$ of the municipalities.

It is worth pointing out that in Torres (North Littoral) a nest of Ac. coronatus was found, a species which occurs only as far as Santa Catarina State (SC). The occurrence of this species in Rio Grande do Sul may result from its introduction via plant transportation by the man, through Bela Torre (SC), on the other side of the Mampituba river. It is also impossible to rule out the hypothesis of still-winged recently fertilized females having crossed the river. 
Table 1. Species of leaf-cutting ants belonging to the Attina subtribe found in municipalities of the North Littoral of Rio Grande do Sul, Brazil (RS, 1994 - 1997).

\begin{tabular}{|c|c|c|}
\hline Species & Municipalities & $\mathrm{N}^{\circ}$ and $\%$ of municipalities \\
\hline A.sexdens & $\begin{array}{l}\text { Santo Antônio da Patrulha, } \\
\text { Gravataí, Osório, Viamão. }\end{array}$ & $4(6.15 \%)$ \\
\hline Ac. ambiguus & $\begin{array}{l}\text { Torres, Arroio do Sal, Capão da } \\
\text { Canoa, Imbé, Tramandai, } \\
\text { Xangrilá, Osório, Santo Antônio } \\
\text { da Patrulha. }\end{array}$ & $8(12.31 \%)$ \\
\hline Ac. aspersus & $\begin{array}{l}\text { Torres, Osório, Santo Antônio da } \\
\text { Patrulha. }\end{array}$ & $3(4,62 \%)$ \\
\hline Ac. coronatus & $\begin{array}{l}\text { Only Torres (probable recent } \\
\text { introduction). }\end{array}$ & $1(1.54 \%)$ \\
\hline Ac. crassispinus & $\begin{array}{l}\text { Torres, Tramandaí, Imbé, Arroio } \\
\text { do Sal, Capão da Canoa, } \\
\text { Gravataí, Osório, Santo Antônio } \\
\text { da Patrulha. }\end{array}$ & $8(12.31 \%)$ \\
\hline Ac. heyeri & $\begin{array}{l}\text { Torres, Gravataí, Viamão, Santo } \\
\text { Antônio da Patrulha, Osório, } \\
\text { Arroio do Sal, Tramandaí, Imbé, } \\
\text { Capão da Canoa, Xangrilá, } \\
\text { Pinhal. }\end{array}$ & $11(16.92 \%)$ \\
\hline A. hispidusfallax & $\begin{array}{l}\text { According to Gonçalves (1961) } \\
\text { throughout Rio Grande do Sul. }\end{array}$ & 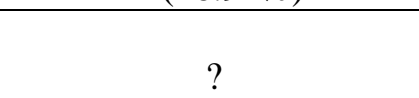 \\
\hline Ac. laticeps & $\begin{array}{l}\text { Torres, Capão da } \\
\text { Tramandaí, } \quad \text { Panoa, } \\
\text { Gravataí. }\end{array}$ & $6(9.23 \%)$ \\
\hline Ac.landoltibalzani & $\begin{array}{l}\text { Torres, Capão da Canoa, } \\
\text { Xangrilá, Tramandaí, Gravataí, } \\
\text { Viamão. }\end{array}$ & $6(9.23 \%)$ \\
\hline Ac. lobicornis & Viamão, Pinhal. & $2(3.08 \%)$ \\
\hline Ac. lundi & Gravataí, Viamão, Pinhal. & $3(4.62 \%)$ \\
\hline Ac. niger & Gravataí, Viamão. & $2(3.08 \%)$ \\
\hline Ac. rugosus & $\begin{array}{l}\text { According to Gonçalves (1961) } \\
\text { throughout Rio Grande do Sul. }\end{array}$ & $?$ \\
\hline Ac. striatus & $\begin{array}{l}\text { Torres, Arroio do Sal, Imbé, } \\
\text { Tramandaí, Gravataí, Osório, } \\
\text { Santo Antônio da Patrulha, } \\
\text { Viamão, Pinhal. }\end{array}$ & $9(13.85 \%)$ \\
\hline \multirow[t]{2}{*}{ Ac. subterraneus } & Tramandaí, Osório. & $2(3.08 \%)$ \\
\hline & $\begin{array}{l}\mathrm{N}^{\circ} \text { and } \% \text { of municipalities where } \\
\text { leaf-cutting ants were found }\end{array}$ & $65(100 \%)$ \\
\hline
\end{tabular}


Table 2. Species of leaf-cutting ants of the Attina subtribe found in counties of the Taquari Valley in Rio Grande do Sul, Brazil (RS, 1994 - 1997).

\begin{tabular}{|c|c|c|}
\hline Species & Municipalities & $\mathrm{N}^{\circ}$ and $\%$ of municipalities \\
\hline A. sexdens & $\begin{array}{l}\text { Porto Alegre. All the other } \\
\text { municipalities of Rio Grande do } \\
\text { Sul, except for those in the North } \\
\text { and South Littoral. }\end{array}$ & $? ?$ \\
\hline Ac. ambiguus & $\begin{array}{l}\text { Porto Alegre, Canela, Gramado, } \\
\text { Três Coroas, Sapiranga, Santa } \\
\text { Maria. }\end{array}$ & $6(8.00 \%)$ \\
\hline Ac. aspersus & $\begin{array}{l}\text { Porto Alegre, Canela, Eldorado } \\
\text { do Sul. Barra do Ribeiro, Guaíba, } \\
\text { Camaquã. }\end{array}$ & $6(8.00 \%)$ \\
\hline Ac. crassispinus & $\begin{array}{l}\text { Porto Alegre Barra do Ribeiro, } \\
\text { Eldorado do Sul, Guaíba, Canoas, } \\
\text { Esteio, Sapucaia do Sul, São } \\
\text { Leopoldo, Santa Bárbara, } \\
\text { Salvador do Sul, Taquari. }\end{array}$ & $11(14.67 \%)$ \\
\hline Ac. heyeri & $\begin{array}{l}\text { Porto Alegre, Camaquã, } \\
\text { Maria, Santa } \\
\text { Lourenço, Taquari. }\end{array}$ & $6(8.00 \%)$ \\
\hline Ac.hispidusfallax & $\begin{array}{l}\text { According to Gonçalves (1961) } \\
\text { throughout Rio Grande do Sul. }\end{array}$ & $? ?$ \\
\hline Ac.landoltibalzani & $\begin{array}{l}\text { Porto Alegre, Sapiranga, Novo } \\
\text { Hamburgo, São Leopoldo, } \\
\text { Sapucaia do Sul, Esteio. }\end{array}$ & $6(8.00 \%)$ \\
\hline Ac. laticeps & 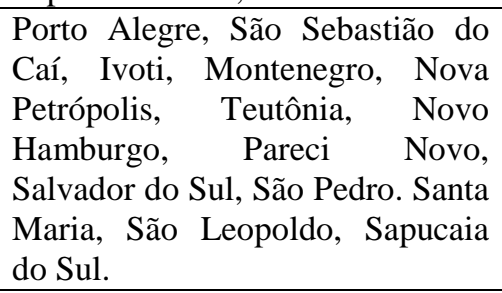 & $13(17.33 \%)$ \\
\hline Ac. lobicornis & $\begin{array}{l}\text { Porto Alegre, Butiá, Júlio de } \\
\text { Castilhos, } \\
\text { Leopoldo. }\end{array}$ & $5(6.67 \%)$ \\
\hline Ac. lundi & $\begin{array}{l}\text { Porto Alegre, Caçapava do Sul, } \\
\text { Santa Cruz do Sul, Santa Maria. }\end{array}$ & $4(5.33 \%)$ \\
\hline Ac. niger & $\begin{array}{l}\text { Porto Alegre, Dois Irmãos, } \\
\text { Sapiranga, São Leopoldo. }\end{array}$ & $4(5.33 \%)$ \\
\hline Ac. rugosus & $\begin{array}{l}\text { According to Gonçalves (1961) } \\
\text { throughout Rio Grande do Sul. }\end{array}$ & $? ?$ \\
\hline Ac. striatus & $\begin{array}{l}\text { Porto Alegre, Barra do Ribeiro, } \\
\text { Camaquã, Eldorado do Sul, Nova } \\
\text { Hartz, Nova Petrópolis, Salvador } \\
\text { do Sul, São Leopoldo, Sapiranga, } \\
\text { Taquara. }\end{array}$ & $11(14.67 \%)$ \\
\hline \multirow[t]{2}{*}{ Ac. subterraneus } & $\begin{array}{l}\text { Porto Alegre, Nova Petrópolis, } \\
\text { São Leopoldo. }\end{array}$ & $3(4.00 \%)$ \\
\hline & $\begin{array}{l}\mathrm{N}^{\circ} \text { and } \% \text { of municipalities where } \\
\text { leaf-cutting ants were found }\end{array}$ & $75(100 \%)$ \\
\hline
\end{tabular}




\section{CONCLUSIONS}

The most frequently found leaf-cutting ant in the Taquari Valley was Atta sexdens although the species was not found in the North Littoral. Of the Acromyrmex genus 16 species occurred in both biogeographic provinces, although not all species were found in the same region, and they presented different frequencies in different municipalities as well. The verification of the occurrence of leaf-cutting ants in geomorphological regions of Rio Grande do Sul may bring about significant subsidies for their control techniques, besides playing a major role for the knowledge of these ants' dispersal over this staying.

\section{ACKNOWLEDGEMENTS}

To Dr. Jacques Delabie who was of great help in identifying some species, and to Dr. Antônio Mayhé-Nunes for the identification of some Attini species. To Dr. Evoneo Berti Filho for the suggestions.

\section{REFERENCES}

BRANDÃO, C.R.F. 1991. Adendos ao catálogo abreviado das formigas da região Neotropical (Hymenoptera: Formicidae). Revista Brasileira de Entomologia, Curitiba, v. 35, n.2, p. 319-412.

BRANDÃO, C.R.F.; MAHYÉ-NUNES, A.J. 2001. A new fungus-growing ant genus. Mycetagroicusgen, $\mathrm{n}$, with descriptions of three new species and comments on the monophyly of the Attini (Hymenoptera: Formicidae). Sociobiology, v.38, n.3, p. 639 - 635.

BRANSTETTER, M.; JESOVNIK, A.; SOSA-CALVO, J. LLOYD, M.W. FAIRCLOTH, B. G.; BRADY, S.G.; SCHULTZ. T.R. 2017. Dry habitats were crucibles of domestication in the evoluyion of agriculture. Proceedings Royal Society B. 284: 20170095. http://dx.doi.org/10.1098/rspb.2017.0095.

BRIAN, M.V. 1983. Social insects: Ecology and Behavioural Biology. New York: Chapman and Hall. $377 \mathrm{p}$.

CORDAZZO, C. V.; SEELIGER, U. 1995. Guia ilustrado da vegetação costeira no extremo sul do Brasil. Rio Grande. Editora da FURG. 275p.

DELLA LUCIA, 1993. As formigas Cortadeiras. Viçosa. 263p.

DIEHL, E. 1995. Formigas: Organização Social e Ecologia Comportamental. Ed. Unisinos. São Leopoldo. 166p. 
DIEHL, E. 1997. Ocorrência de Acromyrmexem áreas com distintos níveis de perturbação antrópica no Rio Grande do Sul. Acta BiologicaLeopoldensia, São Leopoldo v.19, n.1, p.:165-171.

DIEHL, E.; ROCHA, E. S. DA. 1998.Escolha de solo por fêmeas de Acromyrmexstriatus (Hymenoptera: Formicidae) para construção do ninho. Anais da Sociedade. Entomológica do Brasil, Curitiba. v.27, n.1, p. $41-45$.

JANICKI， J. NARULA, N.; ZIGLER, M.; GUÉNEARD, B.; ECONOMO, E.P. 2016. Visualizing and interacting with large-volume biodiversity data using cliente-server webmapping applications. The design and implmentation of antmpas.org. ecological Informatics v. 32, p. $185-193$.

GONÇALVES, C.R. 1961. O gênero Acromyrmex no Brasil. Studia Entomologica, Rio de Janeiro, v.4, n.1-4, p.113-180.

MAYHÉ-NUNES, A.J. 1993. Chave dicotômica para identificação das formigas cortadeiras.In: Della Lucia, T. M.C. 1993. As formigas cortadeiras. Viçosa, MG. 262p.

MAYHÉ-NUNES, A. J.; DIEHL, E. 1994. Distribuição de Acromyrmex (Hymenoptera: Formicidae) no Rio Grande do Sul. Acta BiologicaLeopoldensia, São Leopoldo, v.16, n.1, p.115-118.

KEMPF, W.W. 1972. Catálogo abreviado das formigas da região Neotropical (Hymenoptera: Formicidae). Studia Entomologica, São Paulo, v.15, n.1-4, p.3-344.

KUSNEZOV, N, 1949. O gênero Cyphomyrmexna Argentina. Acta ZoologicaLilloana, v.8, p.427-456,

RAMBO, B. 1994. A fisionomia do Rio Grande do Sul. $3^{\text {a }}$ ed. São Leopoldo. Editora Unisinos. $473 p$.

RABELING, C. COVER, S.P.; JOHNSON, R.A.; MUELLER, U.G. 2007. A review of the North American species of the fungus-gardening ant genus Trachymyrmex(Hymenptera; Formicidae). Zootaxa, v.1664, p.1 - 53.

SPECHT, A.; DIEHL, E.; SILVA, M. E. DA. 1994. Atratividade de iscas de Beauveriabassiana (Bals.) Vuil. as formigas do gênero Acromyrmex (Hymenoptera: Formicidae). Anais da Sociedade Entomológica do Brasil, Curitiba. v.23, n.1, p.99 - 104.

WEBER, 1982, Fungus Ants p. 255 - 364. In: HERMANN, H. (ed.) Social Insects, v.IV,Academic Press. New York. 